\title{
Effect of Macro-, Micro- and Nano-Calcium Carbonate on Properties of Cementitious Composites-A Review
}

\author{
Mingli Cao ${ }^{1, *}$, Xing Ming ${ }^{1}$, Kaiyu $\mathrm{He}^{2}, \mathrm{Li} \mathrm{Li}^{1}$ and Shirley Shen ${ }^{3}$ \\ 1 School of Civil Engineering, Dalian University of Technology, Dalian 116024, China; \\ 13774034082@mail.dlut.edu.cn (X.M.); lili_henan@mail.dlut.edu.cn (L.L.) \\ 2 Henan Institute of Metrology, No. 21, Huayuan Road, Zhengzhou 450008, China; hkyzzhn@163.com \\ 3 CSIRO Manufacturing, Gate 5, Normanby Road, Clayton VIC 3168, Australia; shirley.shen@csiro.au \\ * Correspondence: minglic@dlut.edu.cn
}

Received: 12 February 2019; Accepted: 1 March 2019; Published: 7 March 2019

\begin{abstract}
Calcium carbonate is wildly used in cementitious composites at different scales and can affect the properties of cementitious composites through physical effects (such as the filler effect, dilution effect and nucleation effect) and chemical effects. The effects of macro (>1 mm)-, micro $(1 \mu \mathrm{m}-1 \mathrm{~mm})$ - and nano $(<1 \mu \mathrm{m})$-sizes of calcium carbonate on the hydration process, workability, mechanical properties and durability are reviewed. Macro-calcium carbonate mainly acts as an inert filler and can be involved in building the skeletons of hardened cementitious composites to provide part of the strength. Micro-calcium carbonate not only fills the voids between cement grains, but also accelerates the hydration process and affects the workability, mechanical properties and durability through the dilution, nucleation and even chemical effects. Nano-calcium carbonate also has both physical and chemical effects on the properties of cementitious composites, and these effects behave even more effectively than those of micro-calcium carbonate. However, agglomeration of nano-calcium carbonate reduces its enhancement effects remarkably.
\end{abstract}

Keywords: calcium carbonate; hydration process; workability; mechanical properties; durability

\section{Introduction}

Concrete is a kind of multi-component and multi-scale composite. Because of its relatively low price, diverse sources and good durability, concrete is widely used in many kinds of buildings and structures. However, with the massive use of concrete, environmental pollution and resource consumption inevitably happen. Cement is a necessary raw material for concrete production, on the other hand, cement manufacture is also one of the most energy intensive industries among mineral process industries [1]. According to data from the U.S. Geological Survey in 2017, global cement production reached approximately 4.2 billion tons [2] and is expected to increase year by year. Moreover, major growth will be foreseen in some developing countries such as China and India [3]. Thus, resource and energy consumption will be an even more serious problem with the increase in cement production. At the same time, 0.87 tons of carbon dioxide will be generated at per ton of cement produced [2]. So, the large amount of carbon dioxide emissions is another severe problem that needs to be solved. Aggregates are also an important constitution of concrete and aggregate consumption is detrimental to the environment as well.

Due to these reasons, supplementary cementitious materials (SCMs) and mineral admixtures are used in concrete or cement manufacture to substitute partial cement or aggregates. Incorporation of SCMs and mineral admixtures such as fly ash, slag, silica fume and limestone is not only an effective way to reduce the carbon dioxide emissions and sources consumption, but also an economic 
and environmentally friendly way to produce cement or concrete, because most SCMs and mineral admixtures are industrial waste products [4]. Among these SCMs and mineral admixtures, limestone is widely used as a kind of filler material [5-9], aggregate [10-13], micro-fiber [14-20] and early strength agent [21] because of its various scales (macro-, micro- and nano-scale) [2,22], morphologies (bulk, granular and fibrous shape), crystal systems (calcite, aragonite, vaterite and amorphous calcium carbonate) [2].

Limestone can be formed of various minerals such as calcite, aragonite, vaterite and amorphous calcium carbonate [2]. Among these, calcite is the most common and stable. So most natural limestone is formed of calcite [23]. It has been confirmed that incorporation of calcium carbonate will not be detrimental to mechanical properties and even has a positive synergic effect on early-age strength, the hydration process, durability and microstructure of cementitious composites [2,22,24-26]. Hence, much research has been conducted to clarify the effect mechanism of calcium carbonate on cement paste, mortar or concrete [7,9,27]. In 1938, Bessey et al. [2] first found the formation of calcium-carboaluminate in the hydration process of cement when calcium carbonate was incorporated, which was called the chemical effect of calcium carbonate, and similar results have been found in later studies [2,22,28-33]. Subsequently, a large number of studies were conducted on the role of calcium carbonate in cement paste, mortar or concrete. Now it is widely accepted that the density of the matrix can be increased when calcium carbonate is incorporated, because of its filler effect, and the hydration process can be accelerated because of its nucleation effect [2,22,34]. When the particle size of calcium carbonate is comparable to cement grains, the dilution effect will be effective to influence the workability and hydration process of cement $[2,35,36]$. However, these effects are not independent and often have a coupling effect on mechanical properties, the hydration process, workability and durability of cementitious composites because of its particle size, content and morphology.

Figure 1 shows the number of publications about using limestone in concrete from 2000 to 2017. Applications of limestone is still a hotspot attracting many researchers, especially in recent years. Based on extensive references and research on the effects of calcium carbonate on properties of cementitious composites, many standards have been set to guide the use of calcium carbonate (limestone) in interground and blended cement production, and these standards are sorted chronologically in Table 1 . It can be found that calcium carbonate is widely used in many countries acting as aggregates, fillers or admixtures and its content varies from country to country because of its various applications and particle sizes.

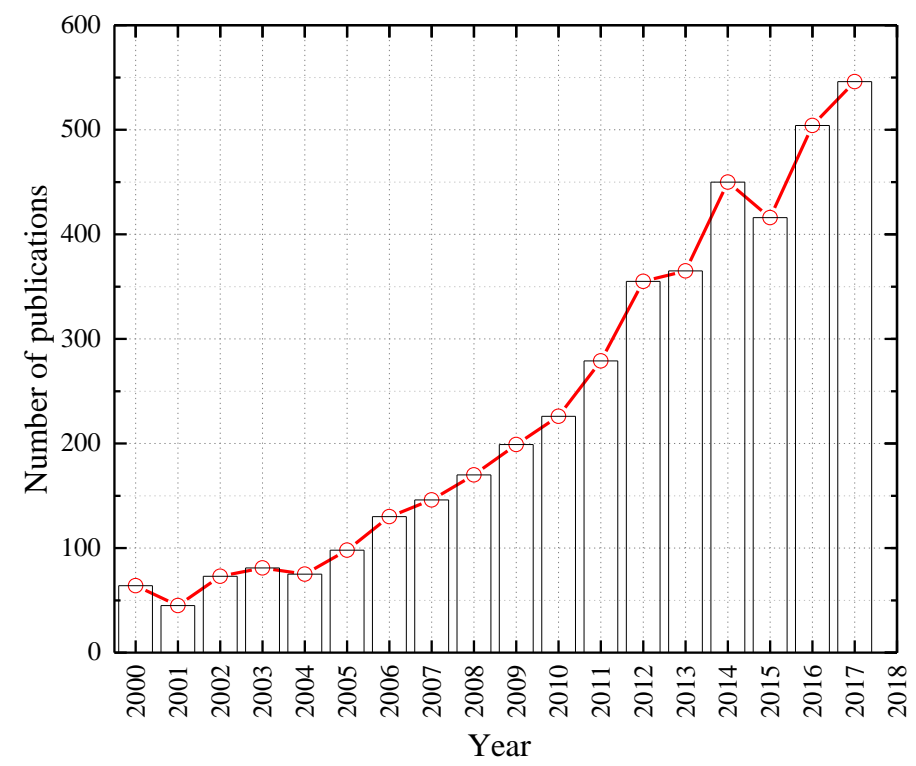

Figure 1. Number of publications per year indexed in Web of Science matching keywords of "concrete and limestone" in search of "Topic". 
Table 1. Standards related to use of limestone in cement production in different areas [1-3,23,25].

\begin{tabular}{cccc}
\hline Date & Area & Standard & Content \\
\hline 1987 & Europe & - & Define Portland-LS cement with 15\% \pm 5\% LS. \\
\hline 1991 & Brazil & NBR 11578/91 & Portland-LS cement can contain from 6\% to 10\% LS fillers. \\
\hline 1999 & Mexico & NMX C-414-0/99 & $\begin{array}{c}\text { Portland-LS cement can contain from 6\% to 35\% LS fillers. } \\
\text { Define different four types of Portland-LS cement containing } \\
\text { 6-20\% limestone (types II/ A-L and II/A-LL) and 21-35\% } \\
\text { limestone (types II/B-L and II/B-LL), respectively. }\end{array}$ \\
\hline 2000 & Europe & EN 197-1 & LS can act as an inactive mixture in cement production. \\
\hline 2007 & Argentina & IRAM 50000/07 & Portland-LS cement can cantina up to 25\% of \\
calcareous materials.
\end{tabular}

Because many studies have been conducted on the effects of calcium carbonate on properties of cementitious composites from fresh mixtures to hardened products, this review focuses on particle size of calcium carbonate and the influence of macro-, micro- and nano-calcium carbonate on the hydration process, mechanical properties, workability and durability of cementitious composites. Moreover, through the summaries of previous references, some constructive suggestions and expectations are proposed as well.

\section{Macro-Calcium Carbonate}

Macro-calcium carbonate refers to calcium carbonate with particle sizes of a millimetric $(>1 \mathrm{~mm})$ level, such as coarse limestone aggregates [10,11] and coarse limestone sand [13]. At this scale, the chemical and nucleation effects of calcium carbonate are not significant and thereby the influence of macro-calcium carbonate on the hydration process is negligible. However, the water absorption, particle size and constitution of macro-calcium carbonate aggregates (coarse limestone aggregates) are effective to influence the workability, mechanical properties and durability of cementitious composites.

\subsection{Workability}

The coarse and fine aggregates generally occupy $70-80 \%$ of the concrete volume and the water absorption of coarse aggregates significantly influences the fresh properties of cementitious composites [11]. It has been found through investigation that slump loss of fresh concrete is most significant in the first $15 \mathrm{~min}$ and dry coarse limestone aggregates causes a higher slump loss compared with the wet one because fresh concrete containing dry coarse limestone aggregates have a higher effective water to cement ratio [11]. Moreover, the workability of fresh concrete also depends on the surfacing filling and particle size of the coarse limestone aggregates. When the fineness modulus of aggregates decreased, the coarse limestone aggregates ratio decreased. Thus, more water is required to achieve the desired workability [37].

\subsection{Mechanical Properties}

The mechanical properties of concrete depend on water absorption, particle size and constitutions of coarse limestone aggregates. Incorporation of wet coarse limestone aggregates can generate a concrete with higher compressive strength compared with incorporation of the dry one [11]. In addition, utilization of smaller particle size aggregates may produce a higher compressive strength, as shown in Table 2 [37]. When the coarse limestone aggregate dimension is $0-5 \mathrm{~mm}$, the compressive strength of 
hardened concrete is up to $42.12 \mathrm{MPa}(\mathrm{w} / \mathrm{c}=0.33-0.36,28 \mathrm{~d})$. At the same time, when partial mountain sand is replaced by limestone aggregates with a grain size less than $5 \mathrm{~mm}$, the drying shrinkage of hardened concrete will also decrease [38].

Table 2. Compressive strength of concrete in different water to cement ratio and curing days (unit: MPa) [37].

\begin{tabular}{|c|c|c|c|c|c|c|c|c|c|c|c|c|}
\hline $\begin{array}{c}\text { Aggregate } \\
\text { Dimension }(\mathrm{mm})\end{array}$ & \multicolumn{3}{|c|}{$w / c=0.33-0.36$} & \multicolumn{3}{|c|}{$\mathrm{w} / \mathrm{c}=0.3$} & \multicolumn{3}{|c|}{$\mathrm{w} / \mathrm{c}=0.4$} & \multicolumn{3}{|c|}{$\mathrm{w} / \mathrm{c}=0.5$} \\
\hline $0-5$ & 11.86 & 19.92 & 42.12 & 12.44 & 20.51 & 42.34 & 11.21 & 19.82 & 42.08 & 7.47 & 16.69 & 34.95 \\
\hline $0-20$ & 8.04 & 17.21 & 35.23 & 7.46 & 17.12 & 34.78 & 8.78 & 17.39 & 35.73 & 7.48 & 11.08 & 22.35 \\
\hline $5-10$ & 8.19 & 14.87 & 29.75 & 7.29 & 14.82 & 30.33 & 9.06 & 14.95 & 28.69 & 5.58 & 10.61 & 20.39 \\
\hline $10-20$ & 8.63 & 8.56 & 18.36 & 4.99 & 7.27 & 17.41 & 6.33 & 12.31 & 20.43 & 3.24 & 6.46 & 12.42 \\
\hline
\end{tabular}

The constitution of coarse limestone aggregates influences the strengths and elastic modulus of concrete, especially for high strength concrete (HSC). Due to its low water to cement ratio, the strengths of HSC are determined by the strengths of aggregates, rather than the bond strength between cement paste and coarse aggregates $[39,40]$. Therefore, it is the mineralogy and strength that control the ultimate strength of HSC. Compared with the different constitutions of coarse limestone aggregates such as calcareous limestone aggregate ( $85 \%$ calcite), dolomitic limestone aggregate ( $80 \%$ dolomite) and quartzitic-gravel aggregate containing schist, dolomite limestone concrete has the highest compressive strength [40]. Beshr and Almusallam [39,40] also obtained similar results when comparing four kinds of coarse aggregates (calcareous limestone, dolomitic limestone, quartzite limestone and steel slag). In addition, they also found that the steel slag concrete had the highest split tensile strength and elastic modulus, followed by that of concrete specimens prepared with the quartzitic, dolomitic and calcareous limestone aggregates because of soft nature of calcareous limestone aggregates. These results have also been proved by the loss on abrasion in different coarse aggregates as shown in Table 3 [39]. However, incorporation of some SCMs such as silica fume, the split tensile strength may increase because of the reaction of calcium hydroxide $\left(\mathrm{Ca}(\mathrm{OH})_{2}\right)$ and silica fume. Thus, concrete prepared with mineral aggregates, such as dolomitic and calcareous limestone aggregates, has a significant improvement in split tensile strength, especially for 90d-strength [40].

Table 3. Loss on abrasion in the coarse aggregates [39].

\begin{tabular}{cc}
\hline Type of Aggregate & Loss on Abrasion (\%) \\
\hline Calcareous limestone & 34.4 \\
Dolomitic limestone & 24.2 \\
Quartzitic limestone & 19.2 \\
Steel slag & 11.6 \\
\hline
\end{tabular}

\subsection{Durability}

According to what is known, incorporation of limestone aggregates in concrete can affect its durability [25], especially the acid resistance and fire resistance.

\subsubsection{Acid Attack}

Concrete used for sewer structures is often attacked by sulfuric acid converted from hydrogen sulfide by bacterial action [13]. To reduce the damage of concrete in an acid condition, there are two effective ways. First, incorporation of SCMs such as fly ash and silica fume in concrete is effective in the reduction of acid attack because of the decreased presence of $\mathrm{Ca}(\mathrm{OH})_{2}$, which reacts with acid [41]. Second, usage of a sacrificial medium can reduce the acid concentration near the concrete surface and decrease the rate of deterioration in concrete subjected to acid attack. Calcareous limestone aggregates could act as a sacrificial medium to neutralize the acidic environment and reduce the $\mathrm{pH}$ value [13]. 
In addition, the calcareous limestone aggregate concrete has an excellent sulfuric acid attack resistance ability when SCMs are incorporated in it.

\subsubsection{High Temperature Exposure}

The compressive strength of concrete after exposure to high temperatures significantly depends on the type of aggregates. The compressive strengths of limestone and siliceous aggregate concrete after exposure to high temperatures have been compared [42,43]. Limestone aggregate concrete has a higher thermal stability compared with the siliceous aggregate concrete, because quartz in siliceous aggregates polymorphically changes at $570{ }^{\circ} \mathrm{C}$ with a volume expiation but the decomposition of calcium carbonate is at $800-900{ }^{\circ} \mathrm{C}[42,44]$. However, due to the functions of internal autoclaving, secondary hydration of unhydrated clinkers and SCMs, and the pozzolanic effect, the post-fire strength of concrete may have an increasing trend before $300{ }^{\circ} \mathrm{C}$ [43-45], especially for the concrete made with siliceous aggregates [43]. Note that when the temperature exceeds $800{ }^{\circ} \mathrm{C}$, concrete would deteriorate irreversibly regardless of being prepared by limestone or siliceous aggregates.

In conclusion, macro-calcium carbonate such as coarse limestone aggregate plays an important role in controlling workability, mechanical properties and durability of cementitious composites. Incorporation of macro-calcium carbonate in cementitious composites can improve both ambient and post-fire strengths. Moreover, macro-calcium carbonate can be regarded as an inert filler.

\section{Micro-Calcium Carbonate}

Micro-calcium carbonate $(1 \mu \mathrm{m}-1 \mathrm{~mm})$, such as limestone powder and limestone dust, is widely used in cement manufacture as a kind of blended or interground material. Though micro-calcium carbonate has no pozzolanic activity and cannot react with alkaline substances such as $\mathrm{Ca}(\mathrm{OH})_{2}$ and calcium oxide $(\mathrm{CaO})$, incorporation of micro-calcium carbonate in cement can have both physical and chemical effects on the hydration process, workability of fresh mixture and mechanical properties of hardened products. Thus, it is imprecise to regard micro-calcium carbonate as an inert filler, especially when micro-calcium carbonate has a smaller particle size than cement grains or is incorporated in ternary or quaternary blends containing SCMs such as fly ash and metakaolin; in these situations micro-calcium carbonate may participate in the cement hydration process and affect the factors of hydration kinetics and microstructure [46-48]. Finally, the mechanical properties and durability will also be influenced. Therefore, the effect of micro-calcium carbonate on the hydration process, workability, mechanical properties and durability is reviewed in the following section.

\subsection{Hydration Process}

As a micro-calcium carbonate, limestone powder has a higher specific area and surface energy than that of macro-calcium carbonate. So the effects of limestone powder on accumulative hydration heat, the release rate of hydration heat and the hydration products of cementitious composites are different from that of macro-calcium carbonate and mainly affected by various particle size, content and crystal structure of micro-calcium carbonate. Table 4 shows the main action mechanism of limestone powder on the hydration process of cement paste. According to this table, the main action mechanism of limestone powder on the hydration process is discussed through the following aspects of particle size, content and crystal structure. 
Table 4. Effect of micro-calcium carbonate on cement hydration.

\begin{tabular}{|c|c|c|c|c|c|c|c|}
\hline \multirow{2}{*}{$\begin{array}{l}\text { Author (Date) } \\
\text { [Reference] }\end{array}$} & \multicolumn{2}{|c|}{ Binder } & \multicolumn{2}{|c|}{ Particle Size $(\mu \mathrm{m})$} & \multicolumn{2}{|c|}{ Blaine Fineness $\left(\mathrm{cm}^{2} / \mathrm{g}\right)$} & \multirow{2}{*}{ Main Action Mechanism } \\
\hline & Mass Content (wt.\%) & Volume Content (vol. \%) & LS & PC & LS & PC & \\
\hline $\begin{array}{l}\text { Bonavetti et al. } \\
\text { (2001) [30] }\end{array}$ & $(20 \%) \mathrm{LS}+(80 \%) \mathrm{PC}$ & - & $\mathrm{D}_{61}=13.2$ & $\mathrm{D}_{90}=26.6$ & 7100 & 2850 & Chemical effect \\
\hline $\begin{array}{l}\text { Poppe et al. } \\
\text { (2005) [5] }\end{array}$ & $\begin{array}{l}(0-67 \%) \text { LS + } \\
(33-100 \%) \text { PC }\end{array}$ & - & $\mathrm{D}_{50} \approx 10$ & $\begin{array}{c}\mathrm{D}_{50} \approx 17 \text { (CEM I 42.5R); } \\
\mathrm{D}_{50} \approx 18 \text { (CEM I 52.5); } \\
\mathrm{D}_{50} \approx 10 \text { (CEM I 52.5 HSR LA) }\end{array}$ & 5260 & $\begin{array}{c}2810 \text { (CEM I 42.5R); } \\
2860 \text { (CEM I 52.5); } \\
4180 \text { (CEM I 52.5 HSR LA) }\end{array}$ & $\begin{array}{l}\text { Nucleation effect, } \\
\text { Chemical effect }\end{array}$ \\
\hline $\begin{array}{l}\text { Ye et al. } \\
\text { (2007) [9] }\end{array}$ & $(33-43 \%)$ LS + (57-67\%) PC & - & & - & 5260 & 4200 (CEM I 52.5) & Nucleation effect \\
\hline $\begin{array}{l}\text { Lothenbach et al. } \\
\text { (2008) [49] }\end{array}$ & PC4: (4\%) LS + (96\%) PC & - & Mean particle size: 4 & - & & $\begin{array}{l}4130 \text { (PC); } \\
4290 \text { (PC4) }\end{array}$ & Chemical effect \\
\hline $\begin{array}{l}\text { Weerdt et al. } \\
\text { (2011) [32] }\end{array}$ & $\begin{array}{c}(0-5 \%) \text { LS + (0-35\%) FA + } \\
(65-100 \%) \text { PC }\end{array}$ & - & $\mathrm{D}_{50}=4$ & $\mathrm{D}_{50}=11$ & 8100 & 4500 & Chemical effect \\
\hline $\begin{array}{l}\text { Bentz et al. } \\
\text { (2012) [50] }\end{array}$ & - & $\begin{array}{c}(0-10 \%) \text { LS + (30-40\%) FA } \\
\quad+(55-100 \%) \text { PC }\end{array}$ & $\begin{array}{c}\mathrm{D}_{50} \text { (median particle } \\
\text { size of LS) = 4.4, 16.4; } \\
\text { Nano-LS } \\
(\mathrm{nm}): 50-120\end{array}$ & $\mathrm{D}_{50}($ median particle size $) \approx 20$ & - & 4760 & $\begin{array}{l}\text { Nucleation effect; } \\
\text { Chemical effect }\end{array}$ \\
\hline $\begin{array}{l}\text { Vance et al. } \\
(2013)[47]\end{array}$ & - & $\begin{array}{c}(0-40 \%) \text { LS + (0-10\%) } \\
\text { FA/MK + (50-100\%) PC }\end{array}$ & $\begin{array}{c}\mathrm{D}_{50} \text { (median particle } \\
\text { size })=0.7,3,15\end{array}$ & $\mathrm{D}_{50} \approx 10$ & - & - & $\begin{array}{l}\text { Nucleation }(0.7 \text { and } 3 \mu \mathrm{m} \mathrm{LS}) \\
\text { Chemical effect }\end{array}$ \\
\hline $\begin{array}{l}\text { Zajac et al. } \\
\text { (2014) [51] }\end{array}$ & $\begin{array}{l}\text { Laboratory cement } \\
\text { containing } 15 \% \text { of LS; } \\
\text { Commercial cement } \\
\text { containing } 1 \%, 3 \%, 9 \% \text { of } \\
\text { LS, respectively }\end{array}$ & - & $\begin{array}{c}\mathrm{D}_{50}=8(\mathrm{LS} \text { in } \\
\text { laboratory cement })\end{array}$ & - & $\begin{array}{l}7000 \text { (LS in } \\
\text { laboratory } \\
\text { cement) }\end{array}$ & - & $\begin{array}{l}\text { Nucleation effect; } \\
\text { Chemical effect }\end{array}$ \\
\hline $\begin{array}{l}\text { Thongsanitgarn } \\
\text { et al. (2014) [35] }\end{array}$ & $\begin{array}{c}(0-30 \%) \text { LS + (0-30\%) FA + } \\
(70-100 \%) \text { PC; } \\
(0-15 \%) \text { LS + (85-100\%) FA }\end{array}$ & - & $\begin{array}{l}\text { Maximum particle } \\
\text { size: } 5,20\end{array}$ & - & - & - & $\begin{array}{c}\text { Nucleation effect, } \\
\text { chemical effect }(5 \mu \mathrm{m}) ; \\
\text { Dilution effect }(20 \mu \mathrm{m})\end{array}$ \\
\hline $\begin{array}{l}\text { Bentz et al. } \\
\text { (2015) [26] }\end{array}$ & $\begin{array}{c}(0-10 \%) \mathrm{LS}+(0-20 \%) \mathrm{FA}+ \\
(75-100 \%) \mathrm{PC}\end{array}$ & - & $\begin{array}{c}\mathrm{D}_{50}=1.58 \text { (Fine LS); } \\
\mathrm{D}_{50}=15.7 \text { (Coarse LS); } \\
\mathrm{D}_{50}=7.11 \\
(\text { Mmarblewhite }) \\
\mathrm{D}_{50}=3.09 \text { (Sturcal F); } \\
\mathrm{D}_{50}=1.59(\text { HT Sturcal F) }\end{array}$ & $\begin{aligned} \mathrm{D}_{50} & =10.6 \text { (Type III cement); } \\
\mathrm{D}_{50} & =9.85 \text { (White cement); } \\
\mathrm{D}_{50} & =11.9 \text { (Type I/II cement) }\end{aligned}$ & - & $\begin{array}{l}4810 \text { (Type III cement); } \\
3970 \text { (White cement); } \\
3730 \text { (Type I/II cement) }\end{array}$ & $\begin{array}{c}\text { Nucleation effect } \\
\text { (fine LS and calcite LS); } \\
\text { Chemical effect (fine LS); } \\
\text { Dilution effect } \\
\text { (fine and coarse LS) }\end{array}$ \\
\hline $\begin{array}{l}\text { Schöler et al. } \\
\text { (2015) [29] }\end{array}$ & $\begin{array}{c}(0-20 \%) \mathrm{LS}+(0-30 \%) \mathrm{FA}+ \\
(20-30 \%) \mathrm{BFS}+50 \% \mathrm{PC}\end{array}$ & - & $\mathrm{D}_{50}=16$ & $\mathrm{D}_{50}=11$ & 4650 & 5180 & Chemical effect \\
\hline
\end{tabular}

Notes: LS, PC, MK, FA, BFS represent limestone, Portland cement, metakaolin, fly ash and blast furnace slag, respectively; $\mathrm{D}_{50}, \mathrm{D}_{61}, \mathrm{D}_{90}$ represent the particle sizes of limestone powder when fraction passing are $50 \%, 61 \%$ and $90 \%$, respectively; CEM and HSR LA represent different cement types. 


\subsubsection{Particle Size}

The particle size of micro-calcium carbonate affects its physical effects (the filler effect, dilution effect and nucleation effect) and chemical effects. When a coarser (comparable or coarser than cement grains) limestone powder is used in cementitious composites, the main action effect of limestone is the filler effect. Because of the smaller surface energy and lower dissolution in an alkaline environment, limestone powder hardly participates in the hydration process of cement and may only fill the voids between aggregates such as sand and coarse aggregates. However, when a finer (finer than cement grains) limestone powder is incorporated in cementitious composites, accumulative hydration heat, the release rate of hydration heat and the hydration products are all greatly different. For the chemical effect of micro-calcium carbonate, the results may be interesting. Vance et al. [47] investigated the particle size of limestone powder on cement hydration and three limestone powders of different fineness were used. The finer limestone powder (median particle size $=0.7$ or $3 \mu \mathrm{m}$ ) significantly accelerates the hydration process of calcium silicate and increases the hydration peak (see in Figure 2 [47]), because finer limestone powder has a larger specific area and surface energy and provide additional nucleation sites for the formation and development of calcium silicate hydrate (C-S-H) $[5,9,26,35,47,50,51]$, which is known as nucleation effect. Moreover, the second hydration peak is generally recognized as the hydration of calcium aluminate and will demonstrate a significant improvement when $0.7 \mu \mathrm{m}$ limestone powder is incorporated, which means the formation of new hydration products such as hemicarboaluminate and monocarboaluminate. The formation of carboaluminates has also been confirmed by many other researchers $[5,26,30,51]$. However, hemicarboaluminate is not thermostable and mainly exists in the early hydration process (before $7 \mathrm{~d}$ ), and then slowly converts to monocarboaluminate. The formation of carboaluminate depends on many factors such as kinetics of hemi- and monocarboaluminate formation and the dissolution of calcium carbonate is lower in high $\mathrm{pH}$ conditions, which causes the actual amount of calcium carbonate participating in the formation of carboaluminate to be far less than the content of limestone powder [51]. Therefore, the intensity of the carboaluminates peaks in the X-ray diffraction (XRD) pattern is lower and difficult to detect compared to other hydrates, as shown in Figure 3 [51]. For the second hydration peak, Bentz et al. had a similar result through the investigation of hydration of cement prepared with different fineness of limestone powder [50], and another possibility for the increasing second hydration peak of cement containing fine limestone powder (nano-limestone powder and $4.4 \mu \mathrm{m}$ limestone powder in reference [50]) may be that limestone powder can provide an additional source of calcium irons to the pore solution, even though calcium carbonate has a relatively low dissolution in the elevated $\mathrm{pH}$ condition [50]. When a coarser limestone powder $(15 \mu \mathrm{m}$ in reference [47]; $20 \mu \mathrm{m}$ in reference [35] and $15.7 \mu \mathrm{m}$ in reference [26]) is used in cementitious composites, the dilution effect is also significant. Though the heat release rate of coarse limestone powder-cement is still higher than that of the pure cement, the total hydration heat is comparable or even lower than that of pure cement, as shown in Figure 2 [47].

\subsubsection{Content}

The content of limestone powder can also affect the main action mechanism of limestone powder on cement hydration. In general, the nucleation effect increases with the increase of limestone powder content. This is because more nucleation sites can be provided for the formation of C-S-H and the accumulative hydration. The heat release rate will also increase. The effect of the content of limestone powder on its chemical effect may be complicated for the following two reasons: (1) the formation of hemi- and monocarboaluminate mainly depends on the kinetics rather than the amount of calcium carbonate present; and (2) the dissolution of calcium carbonate is small and the content of aluminate in cement is low as well [51]. However, some quantitative relationships of the chemical effects of limestone powder can still be calculated according to the chemical reaction equations, and the results are shown in Figure 4 [24]. Regions I, II and III are delineated by dotted lines, which means the hydrates in these areas are metastable phases. According to the boundaries in the three areas, the content of 
carboaluminates is the function of the content of sulfate, carbonate and aluminate. There is no calcite in regions I to IV, which means calcite totally participates in the reaction of calcium carbonate and tricalcium aluminate $\left(\mathrm{C}_{3} \mathrm{~A}\right)$. But in regions $\mathrm{V}$ and $\mathrm{VI}$, the calcite just acts as an inert filler to fill the voids between cement grains. Conversely, the dilution effect has a significant enhancement with the increase of limestone powder content, especially for the ultra-fine limestone powder [2]. Because more free water can be substituted by the ultra-fine limestone powder in voids, the effective water to cement ratio increased.

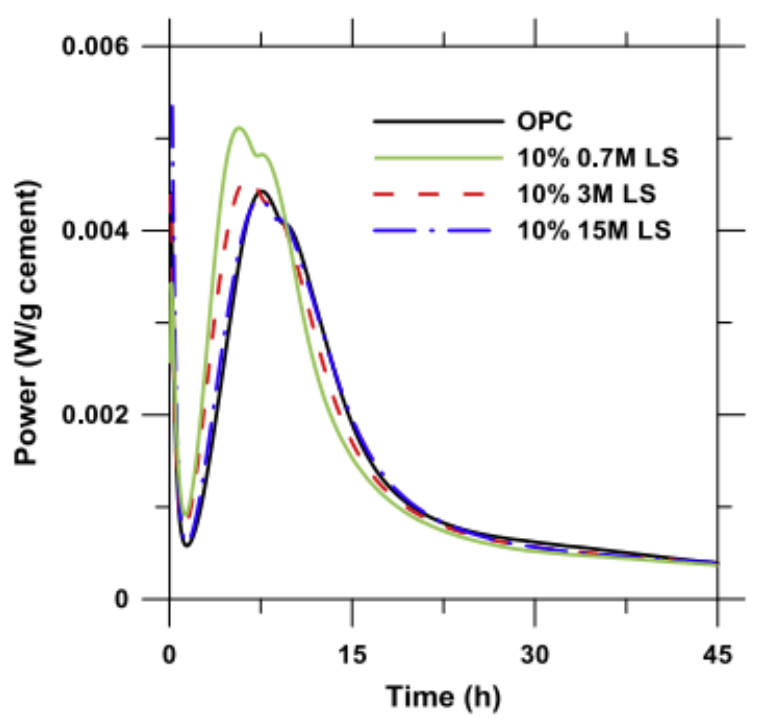

Figure 2. Influence of particle size on the heat release rate [47].
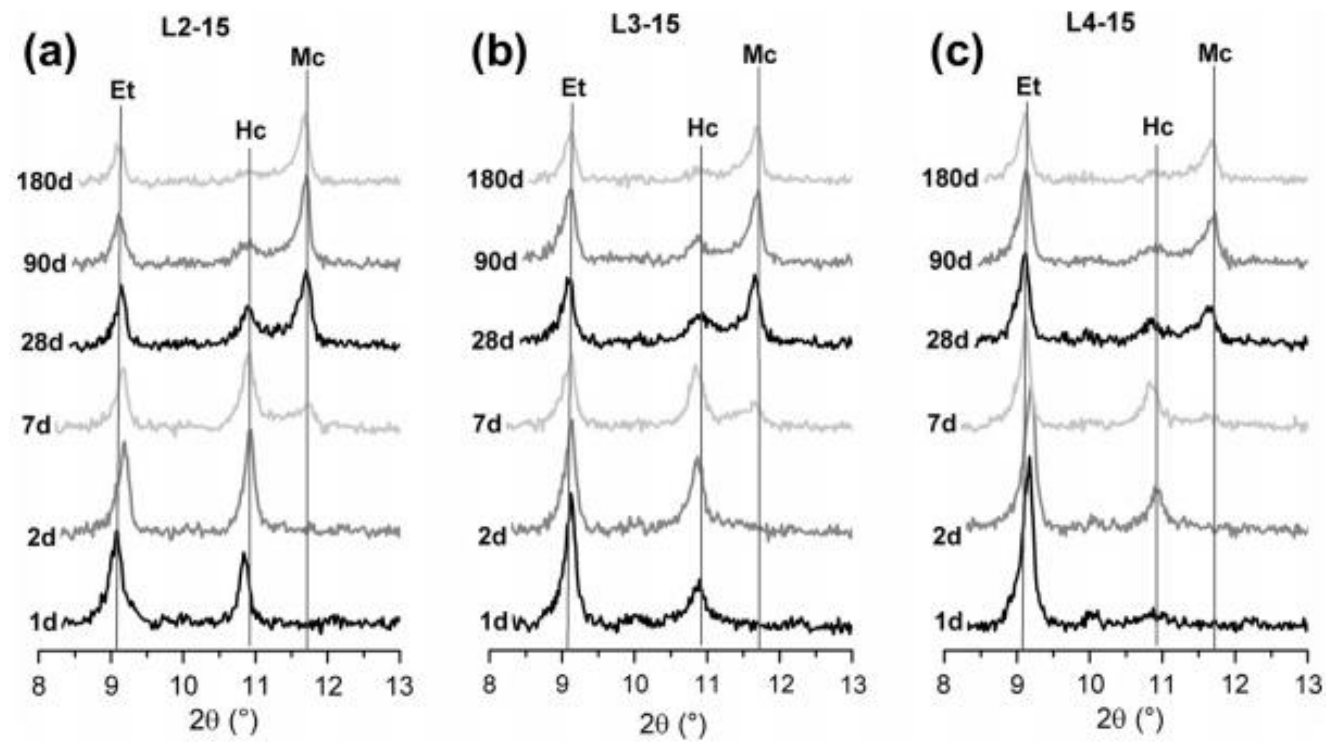

Figure 3. Influence of different quantities of anhydrite on the hydration of laboratory limestone (LS) containing Portland cements: (a) $2.1 \% \mathrm{CaSO}_{4}+15 \% \mathrm{LS}$, (b) $3 \% \mathrm{CaSO}_{4}+15 \% \mathrm{LS}$, and (c) $3.8 \% \mathrm{CaSO}_{4}+$ $15 \%$ LS. The main reflexes of ettringite $(\mathrm{Et})$, hemicarbonate $(\mathrm{Hc})$, monocarbonate $(\mathrm{Mc})$ are indicated [51].

\subsubsection{Crystal Structure}

Limestone powders with different crystal structures may have different influences on cement hydration. The influence of aragonite (sturcal F) and calcite (heat-treated sturcal F) on cement hydration have been investigated [26]. Calcite can significantly accelerate the hydration process, but aragonite may not. As shown in Figure 5 [52], the planar configuration of calcite consists of $\mathrm{Ca}$ and $\mathrm{O}$ atoms, which is similar to the $\mathrm{CaO}$ layer in C-S-H gel. But to aragonite, only $\mathrm{Ca}$ atoms are detected in the 
surface layer for aragonite. So, calcite has an improvement on hydration process. However, because of the similar dissolution processes of calcite and aragonite in an ambient environment, the chemical effect may not be distinguished [26].

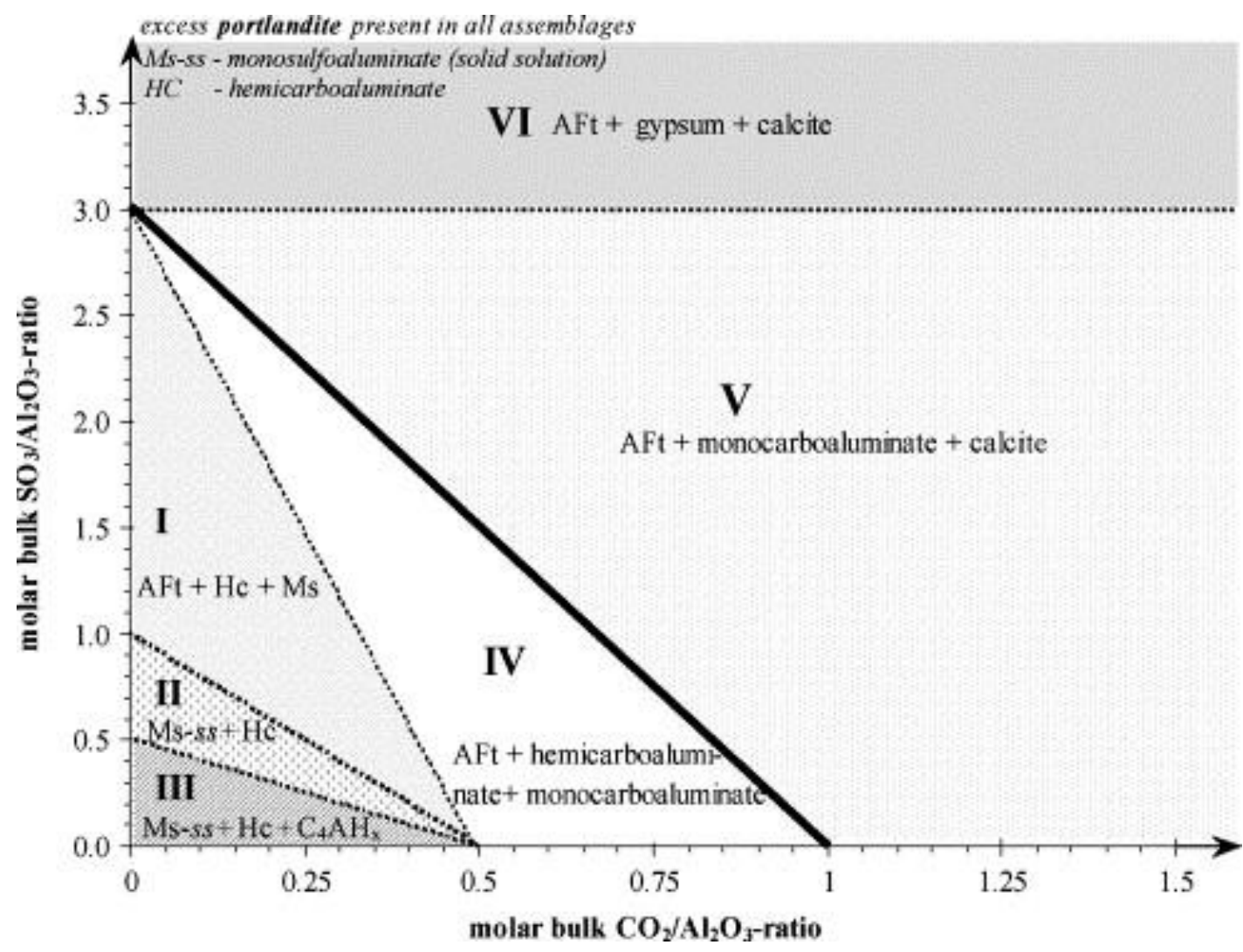

Figure 4. Calculated phase assemblages of a hydrated mixture consisting of $\mathrm{C}_{3} \mathrm{~A}, \mathrm{Ca}(\mathrm{OH})_{2}$ and varying initial sulfate $\left(\mathrm{SO}_{3} / \mathrm{Al}_{2} \mathrm{O}_{3}\right)$ and carbonate ratios $\left(\mathrm{CO}_{2} / \mathrm{Al}_{2} \mathrm{O}_{3}\right)$ at $25^{\circ} \mathrm{C}$ (molar units) [24].
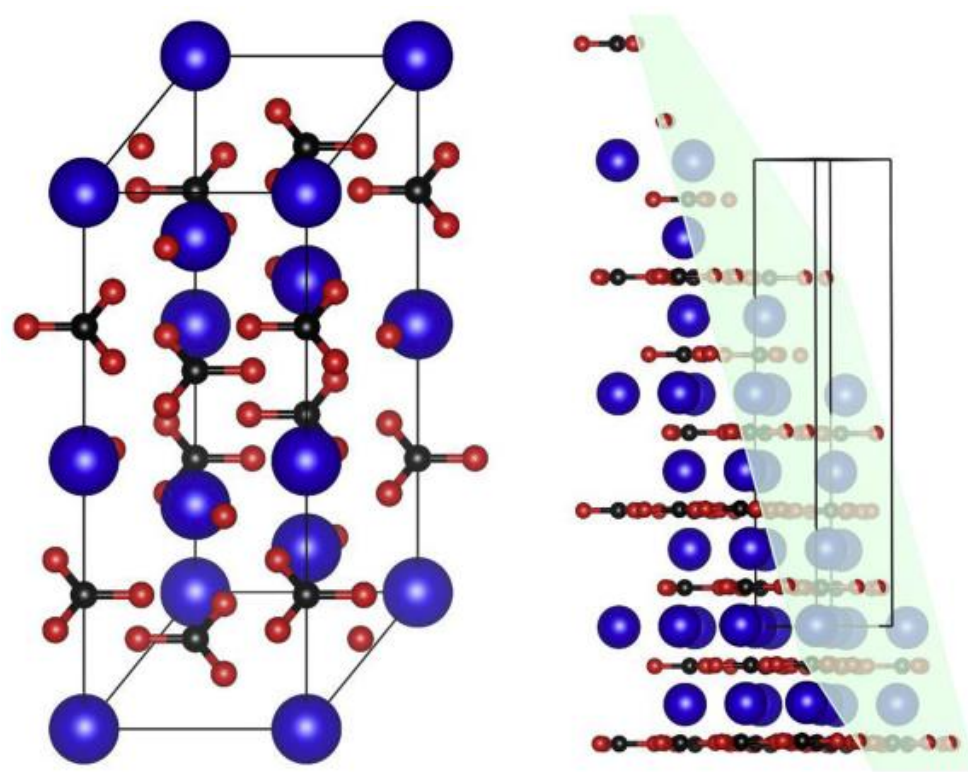

Figure 5. Calcite unit cell general view (left) and dissected by (1014) plane (right). Atom radius is reduced from actual values to allow better visualization. (Ca: large blue atoms; C: small black atoms; O: small red atoms) [52]. 


\subsection{Workability}

The workability of a fresh mixture containing limestone powder mainly depends on its particle size, content and surface morphology. The viscosity (tested by V-funnel time or rheometer) increases with the decrease in particle size of limestone powder, especially when the particle size is comparable or smaller than those of cement grains, because of the fill effect and higher specific area of limestone powder [53]. Therefore, self-compacting concrete (SCC) prepared with fine limestone powder (median particle size $<20 \mu \mathrm{m}$ [53-55]) may have a good segregation resistance ability and workability. The viscosity is also influenced by the replacement content of limestone powder, but it is not a linear relationship between the replacement content and variation of viscosity [53]. The effects of limestone powder on yield stress (tested by spread flow or rheometer) may be complicated. Coarse limestone powder (Blaine fineness $=4430 \mathrm{~cm}^{3} / \mathrm{g}$ ) could reduce the spread flow values (increased the yield stress), but fine limestone powder (Blaine fineness $=5380 \mathrm{~cm}^{3} / \mathrm{g}$ ) increased the spread flow values (decreased the yield stress) [53]. Bentz et al. [52] used a finer limestone powder than that in reference [53] and found that fine limestone powder could increase the flowability and decrease the yield stress. Cao et al. also investigated the effect of morphology of calcium carbonate on viscosity and yield stress of cement mortar containing aragonite calcium carbonate whisker $(\mathrm{CW})$ with a needle-like shape (aspect ratio $=10-60$ ) [56]. Both viscosity and yield stress increase with the increased substitution amount of cement because of its higher specific area. The purity of limestone powder [57] also affects the workability of fresh mixture in addition to the above factors.

\subsection{Mechanical Properties}

\subsubsection{Limestone Powder}

The mechanical properties of cementitious composites containing limestone powder depend on particle size, content and morphology. With the decrease particle size, compressive strength at early-age (before $7 \mathrm{~d}$ ) is found to increase with a constant content of limestone powder [1,47,54,55]. But for long-term age, incorporation of finer limestone powder may decrease the compressive strength [1], because the dilution effect of finer limestone powder may be more effective than its filler effect or nucleation effect at the end stage of the hydration process. With the increased content, compressive strength and flexural strength decrease $[1,47,54,55,58]$. On one hand, a high replacement content reduces the amount of cement and this is not good for the strength development because limestone powder has no cementitious ability. On the other hand, the dilution effect is more effective with the increase in substitution content, and causes a high effective water to cement ratio and lower strength. However, flexural defection of polyvinyl alcohol fiber reinforced engineered cementitious composites (PVA-ECC) may be improved after the addition of limestone powder because of uniform dispersion of PVA fiber caused by the diluting effect of limestone powder [58].

\subsubsection{Calcium Carbonate Whisker}

Calcium carbonate whisker (CW) was first used in the paper industry to enhance the toughness of paper. It is different from limestone powder with a bulk shape [35] or granular shape (see in Figure 6), but is needle-like [56] (see in Figure 7). Because of its shape, CW not only fills the voids to make the matrix dense [14] but also plays a role in resisting the development of micro-cracks, especially with incorporated steel fiber [16,20,59], PVA fiber [15] and carbon fiber [60]. Moreover, a positive synergic effect can be demonstrated when incorporated of a hybrid fiber system [61,62]. 

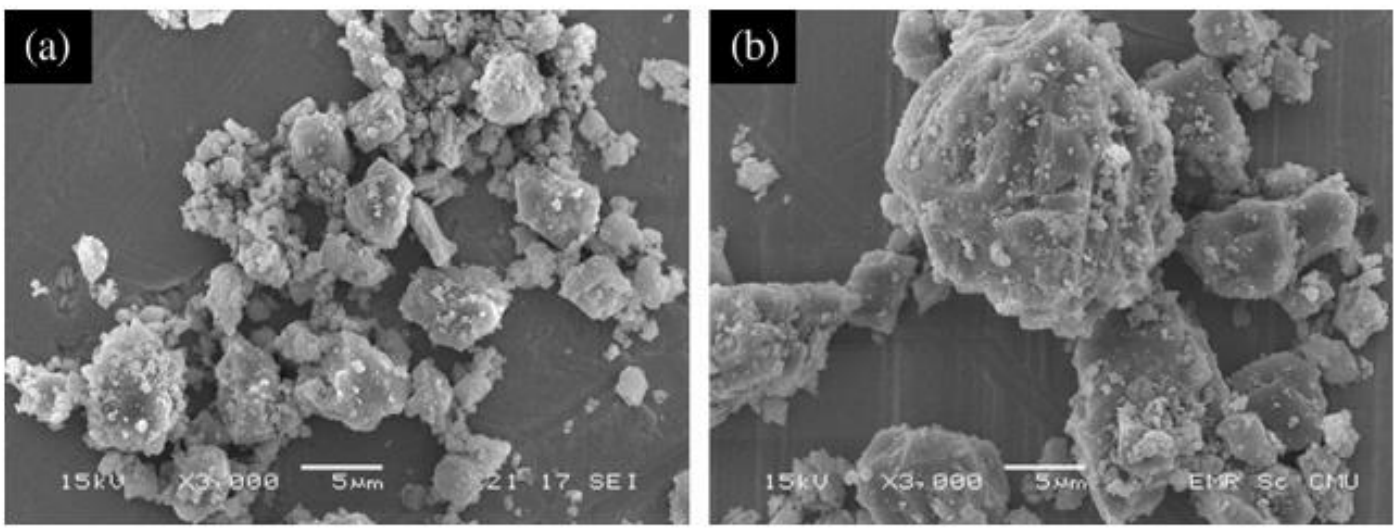

Figure 6. Scanning electron microscopy (SEM) images of limestone powder with particle size of (a) $5 \mu \mathrm{m}$ and (b) $20 \mu \mathrm{m}$ [35].
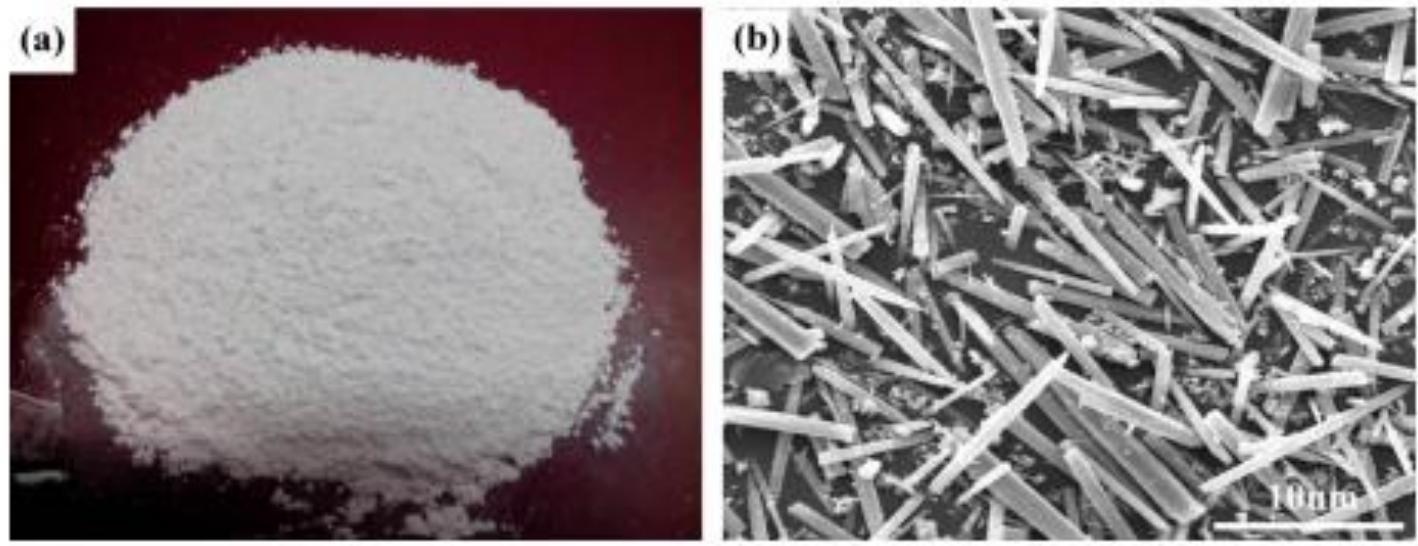

Figure 7. Images of (a) macro-morphology of calcium carbonate whisker (CW); (b) micro-morphology of CW as shown by SEM [56].

\subsection{Durability}

\subsubsection{Acid Attack}

In some special environments, concrete may be attacked by acid. Because of the reaction between $\mathrm{Ca}(\mathrm{OH})_{2}$ produced by the hydration process and acid ions, a high weight loss may occur and, therefore, cause the deterioration of strength. Incorporation of limestone power in cementitious composites can reduce the weight loss $[55,63]$. Moreover, with the increase of substitution content and decrease of particle size, cement mortar or concrete containing limestone powder exhibit a better resistance to acid attack [55]. This is because less $\mathrm{Ca}(\mathrm{OH})_{2}$ is produced when the replacement content of cement is higher. In addition, a finer limestone powder may have a more effective filler effect and make a denser matrix [55]. Thereby, the incorporation of more and finer limestone powder in cementitious composites may give a better resistance to acid attack, to some extent.

\subsubsection{High Temperature Exposure}

Incorporation of limestone powder in cementitious composites may be not good for their ability to resist high temperature exposure. With the increases of temperature and/or content of limestone powder, there are decreases of the compressive strength, ultrasonic pulse velocity (UPV) decrease and increase of weight loss $[64,65]$, especially after the decomposition of calcium carbonate at around $800-900{ }^{\circ} \mathrm{C}[42,44]$.

However, it is noticeable that limestone powder used in these references $[64,65]$ is coarser than cement grains and causes a more effective dilution effect, especially when more cement is 
replaced. Therefore, the residual is lower compared to that without limestone powder before $600{ }^{\circ} \mathrm{C}$. In addition, there are not enough studies about the effects of limestone powder on the properties of high temperature-damaged cementitious composites, especially when the fineness and crystal structure of limestone powder are taken into consideration. So, more studies are needed in this area.

In conclusion, micro-calcium carbonate can affect the hydration process of cement by its dilution effect, nucleation effect and chemical effect. These effects are significantly influenced by the particle size, content and crystal structure. Workability of fresh mixture is also influenced by the particle size and content through the filler effect. Subsequently, mechanical properties and durability are also influenced because of the effect of micro-calcium carbonate on the hydration process and workability. Moreover, the main difference between macro- and micro-calcium carbonate is that micro-calcium carbonate has a chemical effect on cementitious composites, except for the physical effect (filler effect), especially incorporation of finer micro-calcium carbonate (limestone powder) in cementitious composites.

\section{Nano-Calcium Carbonate}

Nanoparticles are commonly defined as materials with a particle size of less than $100 \mathrm{~nm}[66,67]$, and can make revolutionary changes in bulk material properties [68]. Incorporation of nanoparticles in cementitious composites can significantly improve their mechanical properties and durability [67,69-72]. Among these nanoparticles, nano-calcium carbonate is one of the most widely used nanoparticles in the construction sector. In order to distinguish micro-calcium carbonate and nano-calcium carbonate, the particle size of nano-calcium carbonate is less than $1 \mu \mathrm{m}$, rather than being more strictly defined as less than $100 \mathrm{~nm}$. Compared with micro-calcium carbonate, nano-calcium carbonate has a finer particle size and larger specific area, and thereby a more significant effect on the hydration process, workability, mechanical properties and durability of cementitious composites can be observed, even only with a small amount.

\subsection{Hydration Process}

The effect of nano-calcium carbonate on the hydration process of cement depends on its content, particle size and crystal structure [22,73-79]. Sato et al. [73,79] studied the influence of content and particle size of nano-calcium carbonate on cement hydration. Nano-calcium carbonate $(50-120 \mathrm{~nm})$ is very effective in accelerating the cement hydration, especially for the induction period of tricalcium silicate $\left(C_{3} S\right)$, because of its nucleation effect [79]. Moreover, with the increase of calcium carbonate content, the acceleration effect of nano-calcium carbonate is more and more pronounced and the hydration peak of tricalcium aluminate $\left(\mathrm{C}_{3} \mathrm{~A}\right)$ and tetracalcium aluminoferrite $\left(\mathrm{C}_{4} \mathrm{AF}\right)$ is also more and more remarkable. Similar results are also shown in Figure 8 [77]. Both the dormant period and the appearance of the second hydration peak (associated with hydration of $\mathrm{C}_{3} \mathrm{~A}$ and $\mathrm{C}_{4} \mathrm{AF}$ ) are shortened. The reasons are that the calcium ions can be absorbed onto the surface of nano-calcium carbonate when the $\mathrm{C}_{3} \mathrm{~S}$ is dissolved in water because of the high surface energy of nano-calcium carbonate, and thereby it causes the concentration reduction of calcium ions around the $\mathrm{C}_{3} \mathrm{~S}$. It is favorable for accelerating the reaction of $\mathrm{C}_{3} \mathrm{~S}$. In addition, dissolved carbonate ions from nano-calcium carbonate can react with $\mathrm{C}_{3} \mathrm{~A}$ to form hemi- and monocarboaluminates [76,77]. However, nano-calcium carbonate can also react with $\mathrm{C}_{3} \mathrm{~S}$ to form C-S-H gel and $\mathrm{Ca}(\mathrm{OH})_{2}$ and this may be also the reason for earlier and higher hydration heat. The dilution effect of nano-calcium carbonate can also be found in Figure 8 because the mixture containing $4.8 \%$ ( by weight) nano-calcium carbonate $(15-105 \mathrm{~nm}, 97.8 \%$ calcite) has a higher and earlier hydration heat [77], which means nano-calcium carbonate is more effective to perform a dilution effect compared with micro-calcium carbonate (micro-calcium carbonate performs a dilution effect when its content is $10 \%$ (by weight) discussed in Figure 2 [47]). 


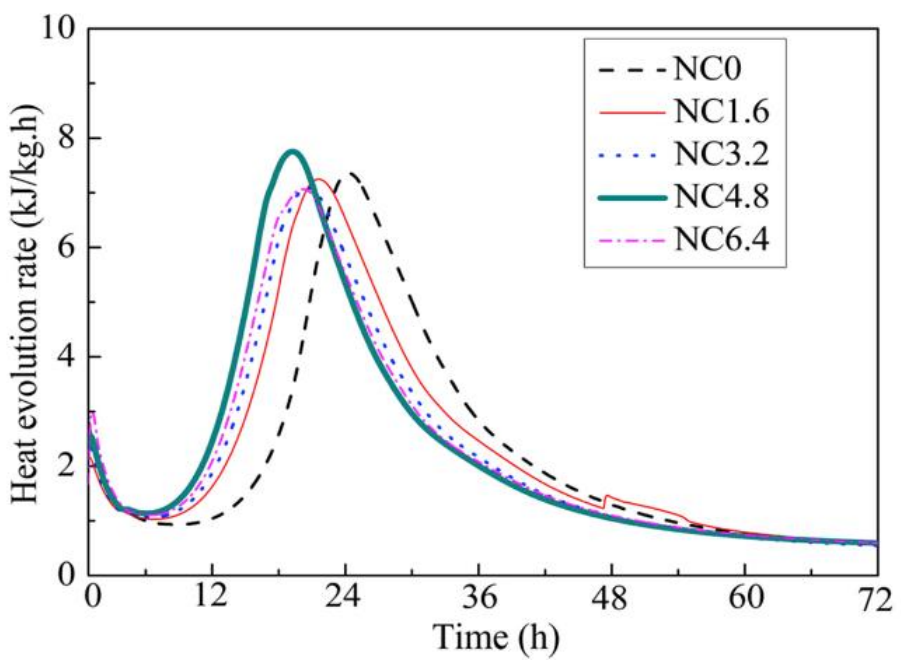

Figure 8. Effects of nano-calcium carbonate contents on heat evolution rate of ultra-high strength concrete (UHSC) [77].

Crystal structure of nano-calcium carbonate can also influence the cement hydration process. The influence of calcite nano-calcium carbonate (NC) and aragonite nano-calcium carbonate (AC) on the properties of PVA-ECC are investigated [78]. From the thermogravimetric analysis (TGA/DTA) in Figure 9, ECC containing $\mathrm{AC}$ has a similar $\mathrm{Ca}(\mathrm{OH})_{2}$ content compared with the control group at $90 \mathrm{~d}$ because the surface structure of aragonite calcium carbonate is less favorable for the formation of C-S-H [78], which means AC is less effective to accelerate the hydration process compared with the NC. These results are similar to that for micro-calcium carbonate [26]. However, the $\mathrm{Ca}(\mathrm{OH})_{2}$ content decreases with the increase of age because of the formation of carboaluminates, carbonation and pozzolanic effect (only for nano-silicon oxide in this reference).

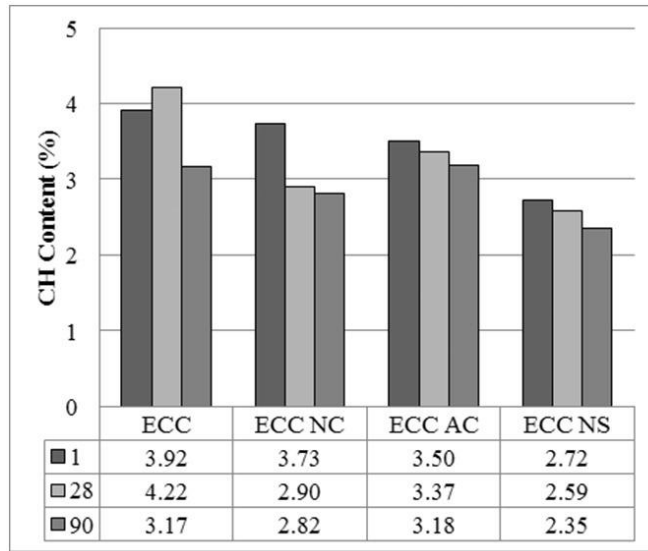

(a)

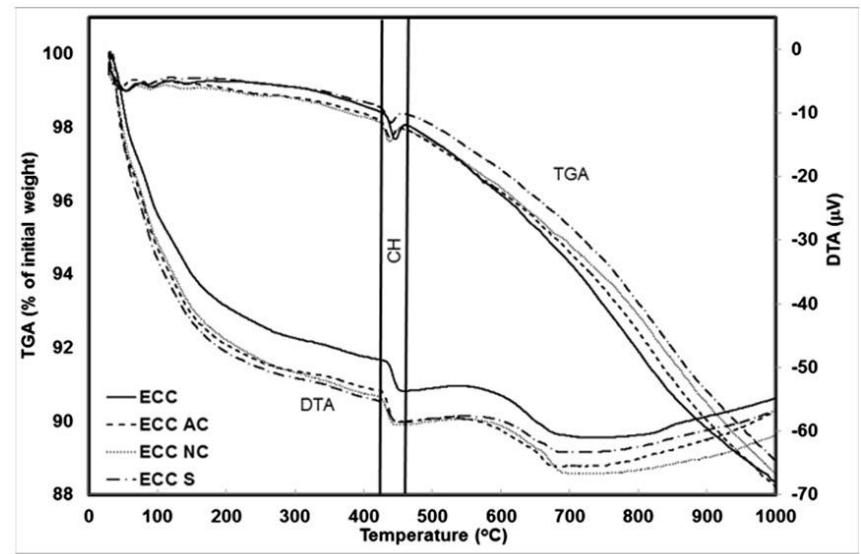

(b)

Figure 9. (a) Change of $\mathrm{Ca}(\mathrm{OH})_{2}$ content of engineered cementitious composite (ECC) mixtures with age. (b) Typical series of thermogravimetric analysis (TGA/DTA) curves of mixtures at the age of 28 days [78].

\subsection{Workability}

The workability of cementitious composites with incorporated nano-calcium carbonate depends on content and particle size. In general, with an increase in particle size or content, the yield stress (spread flow) and viscosity (V-funnel time) increase [27,80,81]. However, when particle size and content of nano-calcium carbonate are taken into consideration at the same time, their combined effect on the workability may be different from the effect of each one. It is generally recognized that 
demanding water of cementitious composites includes two aspects: (1) filling water in the voids between the cement grains; and (2) absorbing water on the surface of cement particles [77]. In addition, the action mechanism may also include two aspects: (1) the dilution effect, which means water in voids can be substituted by nano-calcium carbonate particles; and (2) the filler effect, which means finer nano-calcium carbonate particles can fill the space between cement particles and at the same time, more free water can be absorbed onto the surface of nano-calcium carbonate because of its larger specific area and higher surface energy. Both the two action mechanisms can be influenced by particle size and content of nano-calcium carbonate, and thereby with the increase of content, the flowability may perform differently $[22,75,82]$.

\subsection{Mechanical Properties}

The mechanical properties of cementitious composites containing nano-calcium carbonate mainly depend on their contents. Flexural strength initially increased up to a nano-calcium carbonate (15-40 nm) addition rate of $2 \%$ (by weight) and then decreased [78]. With incorporation of nano-calcium carbonate in PVA-ECC, the mid-span deflection significantly improves, especially at early-age (before $1 \mathrm{~d})$. However, comparing the effect of calcite and aragonite nano-calcium carbonate on flexural and compressive properties, the calcite is more effective because it is more favorable to accelerate the formation of C-S-H [78]. For compressive strength, with the increase in nano-calcium carbonate content, compressive strength initially increases and then decreases $[27,77,81,83]$. The reasons are that, on one hand, nano-calcium carbonate can accelerate the hydration process and react with $\mathrm{C}_{3} \mathrm{~S}$ and $\mathrm{C}_{3} \mathrm{~A}$ to form C-S-H and carboaluminates, and this effect is more effective with the increase of content to some extent. However, when a large amount of cement is replaced by nano-calcium carbonate, the dilution effect is more effective, just like the micro-calcium carbonate. Moreover, agglomeration of nano-calcium carbonate will seriously reduce the development of compression, which is different to micro-calcium carbonate $[1,54,55,58]$. In addition, the denser matrix caused by the addition of nano-calcium carbonate could not provide available space for the formation of hydration products [77]. In general, incorporation of nano-calcium carbonate in cementitious composites can improve early-age strength and incorporation of SCMs may be helpful for long-term strength [84], so the hybrid use of nano-calcium carbonate and SCMs may have a synergic effect on both early-age and long-term strength.

\subsection{Durability}

Very few studies about the effects of acid attack on properties of cementitious composites containing nano-calcium carbonate can be found. However, according to other durability tests such as water sorptivity and chloride permeability [80,85], incorporation of nano-calcium carbonate in cementitious composites can make the matrix dense and reduce the pores. Thus, the impermeability and the acid attack resistance ability may be good, especially when the partial replacement of cement is greater.

For high temperature exposure, incorporation of nano-calcium carbonate in cementitious composites can improve its peak compressive stress, ultimate compressive strain, compressive toughness and flexural properties no matter in ambient environment or in/after high temperature $[68,86,87]$. But it is ineluctable for the rapid decrease in strength after $800{ }^{\circ} \mathrm{C}$ because of the decomposition of calcium carbonate.

In conclusion, just like the micro-calcium carbonate, nano-calcium carbonate can also affect the hydration process, workability, mechanical properties and durability through the filler effect, dilution effect, nucleation effect and chemical effect. All these effects are influenced by the content, particle size and crystal structure of the nano-calcium carbonate. However, the effects of nano-calcium carbonate are more effective than those of micro-calcium carbonate, and it is ineluctable that the agglomeration of nano-calcium carbonate is also more remarkable than that of micro-calcium carbonate because of its higher surface energy and larger specific area. 


\section{Summary and Expectation}

\subsection{Summary}

The effects of macro-, micro- and nano-calcium carbonate on the hydration process, workability, mechanical properties and durability of cementitious composites have been reviewed. Based on the discussion above, conclusions can be drawn as follows:

(1) Macro-calcium carbonate mainly acts as an inert filler in cementitious composites. The influence of macro-calcium carbonate on the cement hydration process is insignificant. The workability of fresh mixture depends on water absorption and particle size of macro-calcium carbonate, and concrete prepared with dry macro-calcium carbonate has a higher slump loss. The mechanical properties of concrete depend on water absorption, particle size and the constitutions of macro-calcium carbonate and concrete prepared with wet and fine macro-calcium carbonate may have a higher strength. Comparison of different mineral aggregates, macro-calcium carbonate (coarse limestone) aggregates are less favorable for the improvement of strength, but incorporation of SCMs in concrete can offset this problem. Macro-calcium carbonate is not a good material to resist an acid attack because of its soft nature. But it is good for resisting high temperature exposure compared with siliceous aggregate, because of its higher thermostability.

(2) Micro-calcium carbonate has both a physical effect (filler effect, dilution effect and nucleation effect) and a chemical effect on cementitious composites. The cement hydration process depends on particle size, content and crystal structure of micro-calcium carbonate. In general, the finer the micro-calcium carbonate particles are, and the higher the content is, the more significant the acceleration effect of the hydration process will be. Moreover, calcite is more favorable in accelerating the hydration process than aragonite, because of their different crystal surface structures. The workability of fresh mixture containing micro-calcium carbonate powder mainly depends on its particle size, content and surface morphology. A finer powder and higher content may cause a higher yield stress and viscosity, but at the same time the dilution effect is also more effective. Therefore, the workability may not have a clear and linear relationship with the particle size or content when all of these factors work together. Conversely, the influence of CW on workability is clearer, and both viscosity and yield stress increase with increased substitution amount of cement. The mechanical properties of cementitious composites containing micro-calcium carbonate depend on its particle size, content and surface morphology. In general, the improvement of micro-calcium carbonate is effective on early-age strength because of its acceleration effect of cement hydration. Incorporation of micro-calcium carbonate in cementitious composites can make the matrix denser and thereby the acid attack resistance ability is better compared with that without micro-calcium carbonate. Incorporation of micro-calcium carbonate in cementitious composites may not be good for its ability to resist high temperature exposure.

(3) Nano-calcium carbonate can have physical and chemical effects on cementitious composites, and these effects of nano-calcium carbonate are more effective compared with those of micro-calcium carbonate. However, the agglomeration of nano-calcium carbonate is also more effective. The effect of nano-calcium carbonate on the hydration process of cement depends on its content, particle size and crystal structure. The hydration process can be accelerated through the nucleation effect and chemical effect. But the dilution effect decreases total hydration heat. The workability of cementitious composites with incorporated nano-calcium carbonate depends on their content and particles. In addition, yield stress and viscosity will perform differently because of the combined effect of particle size and content. Incorporation of nano-calcium carbonate in cementitious composites can improve early-age strength when a proper amount is used. Hybrid use of nano-calcium carbonate and SCMs has a synergic effect both on early-age and long-term strengths. The resistance ability to acid attack of cementitious composites containing nano-calcium carbonate is not clear, but nano-calcium carbonate can make the matrix denser. 
Incorporation of nano-calcium carbonate in cementitious composites is favorable for its high temperature behaviors.

\subsection{Expectation}

There have been many studies about the effect of macro-, micro- and nano-calcium carbonate on properties of cementitious composites. Many effective and significant results and mechanisms have been produced and proposed. But further studies are still needed on:

(1) The high temperature properties of cementitious composites containing calcium carbonate particles. On one hand, the activity and chemical constitutions of calcium carbonate may be different in/after high temperatures. On the other hand, whether incorporation of calcium carbonate is favorable for the high temperature properties of cementitious composites needs more study, especially for aragonite, because a crystal transition will happen at around $450{ }^{\circ} \mathrm{C}$ and the influence of crystal transition on the properties of cementitious composites is still not clear.

(2) Hybrid use of multi-scale calcium carbonate. Macro- and micro-calcium carbonate are more widely used compared with nano-calcium carbonate because nano-calcium carbonate has a relatively high price and is difficult to be dispersed uniformly. Hybrid use of multi-scale calcium carbonate may be a useful way to solve these problems, and thereby more research needs to be conducted to investigate the feasibility and effectiveness of this method.

Author Contributions: M.C. came up the idea and drafted this review. X.M. collected the data and did the literature search. In addition, he completed the manuscript. K.H. revised the manuscript and put lots of useful suggestions. In addition, he helped X.M. optimize the structure and the language expression of this paper. L.L. assisted X.M. to search the relevant literatures and developed the analysis ways. S.S. revised the manuscript and put lots of professional suggestions.

Funding: This research was funded by the National Natural Science Foundation of China under Grant No. 51678111 and No. 51478082. And the APC was also funded by the National Natural Science Foundation of China under Grant No. 51678111.

Conflicts of Interest: We declare that we have no financial and personal relationships with other people or organizations that can inappropriately influence our work. There is no professional or other personal interest of any nature or kind in any product, service and company that could be construed as influencing the position presented in.

\section{References}

1. Kenai, S.; Soboyejo, W.; Soboyejo, A. Some engineering properties of limestone concrete. Mater. Manuf. Process. 2004, 5, 949-961. [CrossRef]

2. Wang, D.; Shi, C.; Farzadnia, N.; Shi, Z.; Jia, H.; Ou, Z. A review on use of limestone powder in cement-based materials: Mechanism, hydration and microstructures. Constr. Build. Mater. 2018, 181, 659-672. [CrossRef]

3. Schneider, M.; Romer, M.; Tschudin, M.; Bolio, H. Sustainable cement production-Present and future. Cem. Concr. Res. 2011, 41, 642-650. [CrossRef]

4. Juenger, M.C.G.; Siddique, R. Recent advances in understanding the role of supplementary cementitious materials in concrete. Cem. Concr. Res. 2015, 78, 71-80. [CrossRef]

5. Poppe, A.; De Schutter, G. Cement hydration in the presence of high filler contents. Cem. Concr. Res. 2005, 35, 2290-2299. [CrossRef]

6. Péra, J.; Husson, S.; Guilhot, B. Influence of finely ground limestone on cement hydration. Cem. Concr. Compos. 1999, 21, 99-105. [CrossRef]

7. Heikal, M.; El-Didamony, H.; Morsy, M.S. Limestone-filled pozzolanic cement. Cem. Concr. Res. 2000, 30, 1827-1834. [CrossRef]

8. Dweck, J.; Buchler, P.M.; Coelho, A.C.V.; Cartledge, F.K. Hydration of a Portland cement blended with calcium carbonate. Thermochim. Acta 2000, 346, 105-113. [CrossRef]

9. Ye, G.; Liu, X.; De Schutter, G.; Poppe, A.M.; Taerwe, L. Influence of limestone powder used as filler in SCC on hydration and microstructure of cement pastes. Cem. Concr. Compos. 2007, 29, 94-102. [CrossRef] 
10. Maslehuddin, M.; Sharif, A.M.; Shameem, M.; Ibrahim, M.; Barry, M.S. Comparison of properties of steel slag and crushed limestone aggregate concretes. Constr. Build Mater. 2003, 17, 105-112. [CrossRef]

11. Alhozaimy, A.M. Effect of absorption of limestone aggregates on strength and slump loss of concrete. Cem. Concr. Compos. 2009, 31, 470-473. [CrossRef]

12. Menadi, B.; Kenai, S.; Khatib, J.; Ait-Mokhtar, A. Strength and durability of concrete incorporating crushed limestone sand. Constr. Build Mater. 2009, 23, 625-633. [CrossRef]

13. Chang, Z.; Song, X.; Munn, R.; Marosszeky, M. Using limestone aggregates and different cements for enhancing resistance of concrete to sulphuric acid attack. Cem. Concr. Res. 2005, 35, 1486-1494. [CrossRef]

14. Cao, M.; Zhang, C.; Lv, H.; Xu, L. Characterization of mechanical behavior and mechanism of calcium carbonate whisker-reinforced cement mortar. Constr. Build. Mater. 2014, 66, 89-97. [CrossRef]

15. Pan, J.; Ca, J.; Ma, H.; Leung, C.K.Y. Development of multiscale fiber-reinforced engineered cementitious composites with PVA Fiber and $\mathrm{CaCO}_{3}$ whisker. Am. Soc. Civ. Eng. 2018, 6, 4018106. [CrossRef]

16. Li, L.; Cao, M. Influence of calcium carbonate whisker and polyvinyl alcohol- steel hybrid fiber on ultrasonic velocity and resonant frequency of cementitious composites. Constr. Build Mater. 2018, 188, 737-746. [CrossRef]

17. Cao, M.; Li, L. New models for predicting workability and toughness of hybrid fiber reinforced cement-based composites. Constr Build Mater. 2018, 176, 618-628. [CrossRef]

18. Cao, M.; Li, L.; Zhang, C.; Feng, J. Behaviour and damage assessment of a new hybrid-fibre-reinforced mortar under impact load. Mag. Concr. Res. 2018, 70, 905-918. [CrossRef]

19. Cao, M.; Li, L.; Xu, L. Relations between rheological and mechanical properties of fiber reinforced mortar. Comput. Concr. 2017, 20, 449-459.

20. Cao, M.; Li, L.; Khan, M. Effect of hybrid fibers, calcium carbonate whisker and coarse sand on mechanical properties of cement-based composites. Mater. Constr. 2018, 68, e156.

21. Liu, J. Influence of $\mathrm{Nano}_{-} \mathrm{CaCO}_{3}$ on Properties of Cement-Based Materials and Its Application. Master's Thesis, Chongqing University, Chongqing, China, 2016. (In Chinese)

22. Camiletti, J.; Soliman, A.M.; Nehdi, M.L. Effects of nano- and micro-limestone addition on early-age properties of ultra-high-performance concrete. Mater. Struct. 2013, 46, 881-898. [CrossRef]

23. Wen, J. Properties and Mechanism of Ground Limestone as Concrete Mineral Additive. Ph.D. Thesis, China General Research Institute of Building Materials, Beijing, China, 2010. (In Chinese)

24. Matschei, T.; Lothenbach, B.; Glasser, F.P. The role of calcium carbonate in cement hydration. Cem. Concr. Res. 2007, 37, 551-558. [CrossRef]

25. Irassar, E.F. Sulfate attack on cementitious materials containing limestone filler-A review. Cem. Concr. Res. 2009, 39, 241-254. [CrossRef]

26. Bentz, D.P.; Ardani, A.; Barrett, T.; Jones, S.Z.; Lootens, D.; Peltz, M.A.; Sato, T.; Stutzman, P.E.; Tanesi, J.; Weiss, W.J. Multi-scale investigation of the performance of limestone in concrete. Constr. Build. Mater. 2015, 75, 1-10. [CrossRef]

27. Liu, X.; Chen, L.; Liu, A.; Wang, X. Effect of $\mathrm{Nano}_{-} \mathrm{CaCO}_{3}$ on properties of cement paste. Energy Proced. 2012, 16, 991-996. [CrossRef]

28. Arora, A.; Sant, G.; Neithalath, N. Ternary blends containing slag and interground/blended limestone: Hydration, strength, and pore structure. Constr. Build. Mater. 2016, 102, 113-124. [CrossRef]

29. Schöler, A.; Lothenbach, B.; Winnefeld, F.; Zajac, M. Hydration of quaternary Portland cement blends containing blast-furnace slag, siliceous fly ash and limestone powder. Cem. Concr. Compos. 2015, 55, 374-382. [CrossRef]

30. Bonavetti, V.L.; Rahhal, V.F.; Irassar, E.F. Studies on the carboaluminate formation in limestone filler-blended cements. Cem. Concr. Res. 2001, 31, 853-859. [CrossRef]

31. Bizzozero, J.; Scrivener, K.L. Limestone reaction in calcium aluminate cement-Calcium sulfate systems. Cem. Concr. Res. 2015, 76, 159-169. [CrossRef]

32. De Weerdt, K.; Haha, M.B.; Le Saout, G.; Kjellsen, K.O.; Justnes, H.; Lothenbach, B. Hydration mechanisms of ternary Portland cements containing limestone powder and fly ash. Cem. Concr. Res. 2011, 41, 279-291. [CrossRef]

33. Kakali, G.; Tsivilis, S.; Aggeli, E.; Bati, M. Hydration products of $\mathrm{C}_{3} \mathrm{~A}, \mathrm{C}_{3} \mathrm{~S}$ and Portland cement in the presence of $\mathrm{CaCO}_{3}$. Cem. Concr. Res. 2000, 30, 1073-1077. [CrossRef] 
34. Soroka, I.; Stern, N. Calcareous fillers and the compressive strength of portland cement. Cem. Conctrete Res. 1976, 6, 367-376. [CrossRef]

35. Thongsanitgarn, P.; Wongkeo, W.; Chaipanich, A.; Poon, C.S. Heat of hydration of Portland high-calcium fly ash cement incorporating limestone powder: Effect of limestone particle size. Constr. Build. Mater. 2014, 66, 410-417. [CrossRef]

36. Das, S.; Aguayo, M.; Dey, V.; Kachala, R.; Mobasher, B.; Sant, G.; Neithalath, N. The fracture response of blended formulations containing limestone powder: Evaluations using two-parameter fracture model and digital image correlation. Cem. Concr. Compos. 2014, 53, 316-326. [CrossRef]

37. Yaşar, E.; Erdoğan, Y.; Kılıç, A. Effect of limestone aggregate type and water-Cement ratio on concrete strength. Mater. Lett. 2004, 58, 772-777. [CrossRef]

38. Aquino, C.; Inoue, M.; Miura, H.; Mizuta, M.; Okamoto, T. The effects of limestone aggregate on concrete properties. Constr. Build. Mater. 2010, 24, 2363-2368. [CrossRef]

39. Beshr, H.; Almusallam, A.A.; Maslehuddin, M. Effect of coarse aggregate quality on the mechanical properties of high strength concrete. Constr. Build. Mater. 2003, 17, 97-103. [CrossRef]

40. Almusallam, A.A.; Beshr, H.; Maslehuddin, M.; Al-Amoudi, O.S.B. Effect of silica fume on the mechanical properties of low quality coarse aggregate concrete. Cem. Concr. Compos. 2004, 26, 891-900. [CrossRef]

41. Caballero, C.E.; Sanchez, E.; Cano, U.; Gonzalez, J.G. On the effect of fly ash on the corrosion properties of reinforced mortars. Corros. Rev. 2000, 18, 105-112. [CrossRef]

42. Arioz, O. Effects of elevated temperatures on properties of concrete. Fire Safety J. 2007, 42, 516-522. [CrossRef]

43. Savva, A.; Manita, P.; Sideris, K.K. Influence of elevated temperatures on the mechanical properties of blended cement concretes prepared with limestone and siliceous aggregates. Cem. Concr. Compos. 2005, 27, 239-248. [CrossRef]

44. Ma, Q.; Guo, R.; Zhao, Z.; Lin, Z.; He, K. Mechanical properties of concrete at high temperature-A review. Constr. Build. Mater. 2015, 93, 371-383. [CrossRef]

45. Xu, Y.; Wong, Y.; Poon, C.S.; Anson, M. Impact of high temperature on PFA concrete. Cem. Concr. Res. 2001, 31, 1065-1073. [CrossRef]

46. Wang, X. Analysis of hydration and strength optimization of cement-fly ash-limestone ternary blended concrete. Constr. Build. Mater. 2018, 166, 130-140. [CrossRef]

47. Vance, K.; Aguayo, M.; Oey, T.; Sant, G.; Neithalath, N. Hydration and strength development in ternary Portland cement blends containing limestone and fly ash or metakaolin. Cem. Concr. Compos. 2013, 39, $93-103$. [CrossRef]

48. Medjigbodo, G.; Rozière, E.; Charrier, K.; Izoret, L.; Loukili, A. Hydration, shrinkage, and durability of ternary binders containing Portland cement, limestone filler and metakaolin. Constr. Build. Mater. 2018, 183, 114-126. [CrossRef]

49. Lothenbach, B.; Le Saout, G.; Gallucci, E.; Scrivener, K. Influence of limestone on the hydration of Portland cements. Cem. Concr. Res. 2008, 38, 848-860. [CrossRef]

50. Bentz, D.P.; Sato, T.; de la Varga, I.; Weiss, W.J. Fine limestone additions to regulate setting in high volume fly ash mixtures. Cem. Concr. Compos. 2012, 34,11-17. [CrossRef]

51. Zajac, M.; Rossberg, A.; Le Saout, G.; Lothenbach, B. Influence of limestone and anhydrite on the hydration of Portland cements. Cem. Concr. Compos. 2014, 46, 99-108. [CrossRef]

52. Bentz, D.P.; Ferraris, C.F.; Jones, S.Z.; Lootens, D.; Zunino, F. Limestone and silica powder replacements for cement: Early-age performance. Cem. Concr. Compos. 2017, 78, 43-56. [CrossRef] [PubMed]

53. Felekoglu, B. Utilisation of high volumes of limestone quarry wastes in concrete industry (self-compacting concrete case). Resour. Conserv. Recycl. 2007, 51,770-791. [CrossRef]

54. Bosiljkov, V.B. SCC mixes with poorly graded aggregate and high volume of limestone filler. Cem. Concr. Res. 2003, 33, 1279-1286. [CrossRef]

55. Lertwattanaruk, P.; Sua-iam, G.; Makul, N. Effects of calcium carbonate powder on the fresh and hardened properties of self-consolidating concrete incorporating untreated rice husk ash. J. Clean. Prod. 2018, 172, 3265-3278. [CrossRef]

56. Cao, M.; Xu, L.; Zhang, C. Rheology, fiber distribution and mechanical properties of calcium carbonate $\left(\mathrm{CaCO}_{3}\right)$ whisker reinforced cement mortar. Compos. Part A Appl. Sci. Manuf. 2016, 90, 662-669. [CrossRef]

57. Chowaniec, O. Limestone Addition in Cement. Ph.D. Thesis, École Polytechnique Fédérale de Lausanne (EPFL), Lausanne, Switzerland, 2012. 
58. Turk, K.; Nehdi, M.L. Coupled effects of limestone powder and high-volume fly ash on mechanical properties of ECC. Constr. Build. Mater. 2018, 164, 185-192. [CrossRef]

59. Cao, M.; Xu, L.; Zhang, C. Rheological and mechanical properties of hybrid fiber reinforced cement mortar. Constr. Build. Mater. 2018, 171, 736-742. [CrossRef]

60. Li, M.; Yang, Y.; Liu, M.; Guo, X.; Zhou, S. Hybrid effect of calcium carbonate whisker and carbon fiber on the mechanical properties and microstructure of oil well cement. Constr. Build. Mater. 2015, 93, 995-1002. [CrossRef]

61. Cao, M.; Zhang, C.; Li, Y.; Wei, J. Using calcium carbonate whisker in hybrid fiber-reinforced cementitious composites. Am. Soc. Civ. Eng. 2014, 27, 4014139. [CrossRef]

62. Zhang, C.; Cao, M. Fiber synergy in multi-scale fiber-reinforced cementitious composites. J. Reinf. Plast. Comp. 2014, 33, 862-874. [CrossRef]

63. Ghrici, M.; Kenai, S.; Said-Mansour, M. Mechanical properties and durability of mortar and concrete containing natural pozzolana and limestone blended cements. Cem. Concr. Compos. 2007, 29, 542-549. [CrossRef]

64. Uysal, M.; Tanyildizi, H. Estimation of compressive strength of self compacting concrete containing polypropylene fiber and mineral additives exposed to high temperature using artificial neural network. Constr. Build. Mater. 2012, 27, 404-414. [CrossRef]

65. Uysal, M. Self-compacting concrete incorporating filler additives: Performance at high temperatures. Constr. Build. Mater. 2012, 26, 701-706. [CrossRef]

66. Sanchez, F.; Sobolev, K. Nanotechnology in concrete-A review. Constr. Build. Mater. 2010, 24, $2060-2071$. [CrossRef]

67. Silvestre, J.; Silvestre, N.; de Brito, J. Review on concrete nanotechnology. Eur. J. Environ. Civ. Eng. 2016, 20, 455-485. [CrossRef]

68. Gao, D.; Zhao, L.; Chen, G. Flexural behavior of fiber and nanoparticle reinforced concrete at high temperatures. Fire Mater. 2018, 42, 725-740. [CrossRef]

69. Sikora, P.; Abd Elrahman, M.; Stephan, D. The Influence of nanomaterials on the thermal resistance of cement-based composites-A Review. Nanomaterials 2018, 8, 465. [CrossRef] [PubMed]

70. Farzadnia, N.; Abang Ali, A.A.; Demirboga, R. Characterization of high strength mortars with nano alumina at elevated temperatures. Cem. Concr. Res. 2013, 54, 43-54. [CrossRef]

71. Qing, Y.; Zenan, Z.; Deyu, K.; Rongshen, C. Influence of nano-SiO ${ }_{2}$ addition on properties of hardened cement paste as compared with silica fume. Constr. Build. Mater. 2007, 21, 539-545. [CrossRef]

72. Han, T.; Wang, H.; Jin, X.; Yang, J.; Lei, Y.; Yang, F.; Yang, X.; Tao, Z.; Guo, Q.; Liu, L. Multiscale carbon nanosphere-carbon fiber reinforcement for cement-based composites with enhanced high-temperature resistance. J. Mater. Sci. 2015, 50, 2038-2048. [CrossRef]

73. Sato, T.; Beaudoin, J.J. Effect of nano- $\mathrm{CaCO}_{3}$ on hydration of cement containing supplementary cementitious materials. Adv. Cem. Res. 2011, 23, 33-43. [CrossRef]

74. Jayapalan, A.R.; Lee, B.Y.; Kurtis, K.E. Can nanotechnology be 'green'? Comparing efficacy of nano and microparticles in cementitious materials. Cem. Concr. Compos. 2013, 36, 16-24. [CrossRef]

75. Camiletti, J.; Soliman, A.M.; Nehdi, M.L. Effect of nano-calcium carbonate on early-age properties of ultra-high-performance concrete. Mag. Concr. Res. 2013, 65, 297-307. [CrossRef]

76. Makar, J.M.; Beaudoin, J.J.; Trischuk, K.; Chan, G.W.; Torres, F. Effect of n-CaCO 3 and metakaolin on hydrated Portland cement. Adv. Cem. Res. 2012, 24, 211-219. [CrossRef]

77. Wu, Z.; Shi, C.; Khayat, K.H.; Wan, S. Effects of different nanomaterials on hardening and performance of ultra-high strength concrete (UHSC). Cem. Concr. Compos. 2016, 70, 24-34. [CrossRef]

78. Yeşilmen, S.; Al-Najjar, Y.; Balav, M.H.; Şahmaran, M.; Yıldırım, G.; Lachemi, M. Nano-modification to improve the ductility of cementitious composites. Cem. Concr. Res. 2015, 76, 170-179. [CrossRef]

79. Sato, T.; Diallo, F. Seeding effect of nano- $\mathrm{CaCO}_{3}$ on the hydration of tricalcium silicate. Transportation research record. J. Trans. Res. Board. 2018, 2141, 61-67. [CrossRef]

80. Shaikh, F.U.A.; Supit, S.W.M. Chloride induced corrosion durability of high volume fly ash concretes containing nano particles. Constr. Build. Mater. 2015, 99, 208-225. [CrossRef]

81. Ge, Z.; Wang, K.; Sun, R.; Huang, D.; Hu, Y. Properties of self-consolidating concrete containing nano-CaCO 3 . J. Sustain. Cement-Based Mater. 2014, 3, 191-200. [CrossRef] 
82. Wang, D.; Shi, C.; Wu, Z.; Wu, L.; Xiang, S.; Pan, X. Effects of nanomaterials on hardening of cement-silica fume-fly ash-based ultra-high-strength concrete. Adv. Cem. Res. 2016, 28, 555-566. [CrossRef]

83. Wu, Z.; Shi, C.; Khayat, K.H. Multi-scale investigation of microstructure, fiber pullout behavior, and mechanical properties of ultra-high performance concrete with nano-CaCO 3 particles. Cem. Concr. Compos. 2018, 86, $255-265$. [CrossRef]

84. Yang, H.; Che, Y.; Leng, F. High volume fly ash mortar containing nano-calcium carbonate as a sustainable cementitious material: microstructure and strength development. Sci. Rep. 2018, 8, 16439. [CrossRef] [PubMed]

85. Shaikh, F.U.A.; Supit, S.W.M. Mechanical and durability properties of high volume fly ash (HVFA) concrete containing calcium carbonate $\left(\mathrm{CaCO}_{3}\right)$ nanoparticles. Constr. Build. Mater. 2014, 70, 309-321. [CrossRef]

86. Gao, D.; Li, H. Compressive stress-strain relationship of fiber and nano sized materials reinforced concrete after exposure to high temperature. China Civ. Eng. J. 2015, 10, 10-20. (In Chinese)

87. Gao, D.; Zhao, L.; Chen, G. Compressive stress-strain relationship of fiber and nanosized material reinforced concrete in high temperature. China Civ. Eng. J. 2017, 9, 46-58. (In Chinese)

(C) 2019 by the authors. Licensee MDPI, Basel, Switzerland. This article is an open access article distributed under the terms and conditions of the Creative Commons Attribution (CC BY) license (http:/ / creativecommons.org/licenses/by/4.0/). 